\title{
Parents Communication Pattern for Schools in the Management of Students with Special Needs
}

\author{
Maulana Amirul Adha \\ Department of Educational Administration \\ Universitas Negeri Malang, Indonesia \\ amirulmaulana1013@gmail.com \\ Nova Syafira Ariyanti \\ Department of Educational Administration \\ Universitas Negeri Malang, Indonesia \\ novasyafira2@gmail.com
}

\author{
Darmaji \\ Department of Educational Administration \\ Universitas Negeri Malang, Indonesia \\ ajidarmaji64@gmail.com \\ Asep Sunandar \\ Department of Educational Administration \\ Universitas Negeri Malang, Indonesia \\ asep.sunandar.fip@um.ac.id
}

\begin{abstract}
This research aims to describe: (1) the school's strategy in communicating the management of students with special needs; and (2) interest parents in the management of students with special needs. This study used a qualitative approach, with a case study research plan. This research place in SD Plus Al-Kautsar Malang city. Data collection techniques with in-depth interviews, observation of roles and documentation. Data analysis techniques used are reduction, display data, and conclude. Results of this study: (1) through the class of parents communicating to the shadow teacher, and the class parents communicate directly to the students' parents; and (2) each year there are always students with special needs who register, empowering shadow Teacher As an intermediary between school and parents and the use of some media as a liaison of parents with schools.
\end{abstract}

Keywords: parents communication, communication pattern, student with special needs

\section{INTRODUCTION}

Individuals who attend education are part of the educational process [1]. The success of education was seen based on individual success in the process and results. Besides, the environment is also part of the success of education, especially in educational institutions that are schools. Therefore, the success of education is not only from the role of the parties in schools such as principals and teachers but the roles of home learning environments and parents [2]. The interaction of students to determine the successful education of educational interactions and non-educative interactions [3].

In addition to the success of education, objects that succeed education are students. Learners in this case who have special needs. Students with special needs are different student groups who need specially adapted learning materials and training to maximize their learning and achievement [4]. Students with special needs mean students who specialize or specialize in treatment when learning. Some of the education in Indonesia has now adopted an inclusion program as one way for equitable education. Proving the development of inclusive education requires educational institution policies aimed at motivating students with special needs to be accepted in the environment in which the learning [5]. In this context, not only at the level of higher education or universities but on primary and upper education. Especially in elementary school.

Currently, it is no longer difficult to find children with special needs to study with their friends in regular schools [6]. Children with special needs that are considered to require education and different devices from their friends who do not have special requirements, were directed to attend a Sekolah Luar Biasa (SLB), but with the spirit that education is the right All children, the regular school begins to open up to equally develop by receiving students with disabilities [7]. Based on the preliminary study conducted by researchers, it was found that SD Plus Al-Kautsar Malang received students with special needs. Students with special needs must be accompanied by an accompanying teacher or called shadow teacher, but the school does not provide the shadow teacher, but the shadow teacher is recruited individually by the parents, to accompany their child to study in class.

The role of parents must be in it or be directly involved in motivating the learners. The rise of bullying, especially in people with disabilities, requires schools to involve the role of parents to give motivation. That way, it is hoped that there is no case for bullying especially for students with special needs. As the results of the study showed that more and more interactions would make them able to explore what was different between the ones he had with other friends, in addition to increasing the confidence needed socialization with Community [8].

Effective cooperation between school and parents is characterized by the involvement of the family to achieve a common goal, namely for the optimal development of children [9]. So parents receive support from schools in the form of knowledge and means that can make them participate fully as a school partner and the school receives input from a family that can support them to teach and to facilitate their children's learning more effectively. One key is to establish good communication [10].

The spirit of normalization for students with special needs in education in the form of inclusion schools requires good cooperation between the school and the parents of students with special needs so that students with special needs can get the benefits of studying in a regular school, not vice versa. Good cooperation pattern requires good communication between the school and the parents [11]. Communication pattern that often leads to misunderstandings between the school and parents, so it is 
necessary to know how effective communication patterns to help optimize the learning of learners with special needs in regular schooling. Based on the above description, the purpose of this research is formulated (1) to know the school strategy in communicating the management of students with special needs, and (2) to know the interest parents in the management of students with needs Special.

\section{Methods}

This research uses a qualitative approach. Qualitative research is a method of exploring and understanding the meaning of many individuals or groups of people coming from social or humanitarian issues [12] Qualitative descriptive research aims to illustrate the characteristic phenomenon with narrative [13]. The data collection techniques used in this study are interviews, study documentation and observation of participation or observation. This research was conducted at SD Plus AlKautsar Malang city.

The step of the study first conducted interviews with teachers, gathered data from the field, and then analyzed the data. Analyses based on data collection techniques result in temporary findings which later researchers undertook to find the essence of the study [14]. Key informant in this research is a class teacher, while other supporting data are additional informants such as Shadow teacher and parent. The legality of data used by researchers to account for data that has been obtained [13], [15]. Data validity checks are credibility. Credibility includes triangulation, member checking, improving persistence, and adequacy of reference material.

\section{RESUlts}

Based on the findings of research conducted by researchers during the field. Research findings are as follows, (1) The school's strategy in communicating the management of students with special needs and (2) interest parents in the management of students with special needs. The school held several programs to support the form of service. One of the programs given by schools is an inclusion school or often called a school that receives students who have special needs. However, learners are not referred to as special-needs children, the worries are feared to continue to the next level. For students with special needs have an agreement with the school that has a shadow teacher. The Shadow teacher must be provided by the student's parents themselves because the students with special needs are unfounded in different classes, but instead, become one with normal learners.

The field findings on the school's strategy in communicating the management of students with special needs are, (1) through the class of parents communicating to the shadow Teacher, and (2) through the class of trustees who directly communicate Parents. These two things became effective when communication between parents and the school was also established. Some of the ways that schools apply, the easiest step is to communicate using electronic tools in the form of social media or when picking up learners is delivered directly.

Communication conducted by the school with parents is about the development of children's learners.
The development of learners can be about cognitive development, affective and psychomotor. On the other hand, there is also a connecting book between the school and parents. The book is about the activities of students conducted during the school, height, weight, and notes to be done at home as supporting activities and learning conducted in the school.

The field findings on the parent's Animo in the management of students with special needs are (1) annually to the year parents of students with special needs are always there, the school limit only receive one student, (2) through the shadow Teacher management of students with special needs can be resolved, parents' beliefs are also increasing. From increased parental participation especially for students with special needs can improve the image of the school, (3) The existence of a book between the school with parents facilitates the management of students with special needs, management The acceptance of new learners together with the school committees, organizing students when going into the classroom, implementing students " learning in the classroom, and evaluating player ratings.

\section{DISCUSSION}

\section{A. The School's Strategy in Communicating the} Management of Students With Special Needs

Based on the findings in the school strategy in communicating the management of students with special needs, through the class that communicates to the shadow teacher, the next through the class that is communicating directly to the learners ' parents. These two things became effective when communication between parents and the school was also established. One of the most effective communications according to Heward [9] A parent and teacher face-to-face meeting, on this method of communication, parents and teachers face-to-face, each exchanging thoughts and information and coordinating each other about their efforts to help children with disabilities At home and school.

The participation of parents in the course of achievement of the optimization of students with special needs is established actively in activities organized by the school. It is in accordance with the opinion of Kowalski [16] which states one of the categories in the school partnership and the Society is coordination. That is, as a partner in improving the quality of learning in schools, parents and school students coordinate various activities in the school. This can be said that if the parents actively participate in school activities, it will facilitate the success of the school in achieving the expected quality.

Some of the ways that schools apply, the easiest step is to communicate using electronic tools in the form of social media or when picking up learners is delivered directly. This communication pattern can be used between the school and parents besides with face to face meeting is also possible to establish communication through social media such as WhatsApp, Facebook, and SMS [17]. Despite the different forms of communication, but the basic principle that is important to be agreed is to keep mutual respect between the school and the child's family with special needs, namely the cooperation of schools and parents have a purpose With the optimal development for children's special needs [18]. 
Communication conducted by the school with parents is about the development of children's learners. The development of learners can be about cognitive development, affective and psychomotor. On the other hand, there is also a connecting book between the school and parents. The book is about the activities of students conducted during the school, height, weight, and notes to be done at home as supporting activities and learning conducted in the school. Face-to-face meetings between the school and the family provide benefits and convenience but due to the bustle of the school parties and students' parents often this meeting cannot be scheduled therefore communication in writing Needed [9].

\section{B. Animo Parents in the Management of Students With Special Needs}

The field findings on the parent's Animo in the management of students with special needs, annually to the years' parents of students with special needs are always there. Students with special needs must be accompanied by an accompanying teacher (shadow teacher), but the school does not provide the shadow teacher, but the shadow teacher is recruited individually by the parents, to accompany their child to study in class. The policy is not an obstacle for the students' parents to enrol their children in school.

The role of parents in child education with special needs has a very vital role. When children enter school, parents are required to proactively communicate with the teachers about their growth and development. [19]. The potential and visible talent of the child is important to be informed to the teacher as input material in providing the right education program for students with special needs [6]. So that in the development of children will grow with his talents.

School policies that parents raise their companion teachers to their children through the shadow teacher management of students with special needs can be resolved, so that parental beliefs are increased. From increased parental participation especially for students with special needs can improve the image of the school [17], Success of the inclusive education program is not separated from managerial efforts [20]. Inclusive education in schools should promote open management of the inputs and critiques that build up from parents, so that common goal can be achieved effectively and efficiently.

Animo parents can be seen from the connecting book between the school and the parents that facilitate the management of students with special needs, the management through several things that the acceptance planning of new learners together With the school committees, organizing students when going into the classroom, implementing student learning in the classroom, and evaluating reports.

This is a method of written communication between the school and the family parties. To use this method of communication should be prudent because the teacher needs to communicate in one language with the parents, while through writing language can not directly get a response stating that the information recipients understand or not Understand [9]. Therefore, the communication is written only to convey the general information and not to discuss the specifics so that it can avoid the unfamiliarity between the school and the parents of students with special needs [21].

\section{Conclusion}

From the result of the above discussion, the conclusion of the study is: (1) the school's strategy in communicating the management of student with special needs is through a class of parents communicating to the shadow teacher, and the class guardian communicates directly to students' parents. The strategy uses the use of electronic media such as social media, liaison books as well as direct meetings with student' parents, and (2) parents in the management of students with special needs of each year there is always students with special needs who register, empowering shadow teacher ad intermediaries between the school and the parents and the use of some media as a liaison parent with the school.

\section{REFERENCES}

[1] J. Preston, "Influencing Community Involvement in School: a School Community Council," McGill J. Educ., vol. 46, no. 2, pp. 197-212, 2011.

[2] C. Baumann and H. Krskova, "School Discipline, School Uniforms and Academic Performance," Int. J. Educ. Manag., vol. 30, no. 6, pp. 1003-1029, 2016.

[3] Sumarsono, R.B. and Imron, A. Manajemen Hubungan dan Partisipasi Masyarakat di Sekolah. Malang: Universitas Negeri Malang, 2017.

[4] J. E. Ormrod, Educational Psychology: Developing Learners, 7th ed. Boston: Pearson Education, Inc., 2011.

[5] M. G. Lavasani and F. Khandan, "Cypriot Journal of Educational," Cypriot J. Educ., vol. 2, no. 1, pp. 61-74, 2011.

[6] A. Qvortrup and L. Qvortrup, "Inclusion: Dimensions of Inclusion in Education," Int. J. Incl. Educ., vol. 22, no. 7, pp. 803-817, 2018.

[7] C. Tjernberg and E. H. Mattson, "Inclusion in Practice: a Matter of School Culture," Eur. J. Spec. Needs Educ., vol. 29, no. 2, pp. 247-256, 2014.

[8] İ. Dalbudak, A. C. Gürkan, Ş. M. Yiğit, M. Kargun, G. Hazar, and F. Dorak, "Investigating visually disabled students' attitudes about physical education and sport," Int. J. Environ. Sci. Educ., vol. 11, no. 16, pp. 9437-9447, 2016.

[9] W.L. Heward, "Exceptional Children: An Introduction to Special Education (8th Edition)," Prentice Hall, 2010. .

[10] S. Miles and N. Singal, "The Education for All and Inclusive Education Debate: Conflict, Contradiction or Opportunity?," Int. J. Incl. Educ., vol. 14, no. 1, pp. 1-15, 2010.

[11] R. B. Sumarsono, A. Imron, B. B. Wiyono, and I. Arifin, "Parents " Participation in Improving the Quality of Elementary School in the City of Malang, East Java , Indonesia," Int. Educ. Stud., vol. 9, no. 10, pp. 256-262, 2016.

[12] J. . Creswell, Research Design: Qualitative, Quantitative, and Mixed Methods Approaches (3rd Ed.), 3rd ed. London: Sage, 2009.

[13] N. Ulfatin, Metode Penelitian Kualitatif di Bidang Pendidikan: Teori dan Aplikasinya. Malang: Media Nusa Creative, 2015.

[14] S. Bogdan, R.C \& Biklen, Qualitative Research for Education An Introduction to Theory and Methods. boston: Allyn and Bacon, Inc., 1982.

[15] J. A. Maxwell and L. E. Reybold, "Qualitative Research," in International Encyclopedia of the Social \& Behavioral Sciences: Second Edition, Elsevier Inc., 2015. 
[16] T. . Kowalski, Public Relations in School. New Jersey: Prentice Hall, 2004.

[17] G. Bedell et al., "Community Participation, Supports, and Barriers of School-Age Children with and Without Special needs," Arch. Phys. Med. Rehabil., vol. 94, no. 2, pp. 315$323,2013$.

[18] T. Day and A. Prunty, "Responding to the Challenges of Inclusion in Irish Schools," Eur. J. Spec. Needs Educ., vol. 30, no. 2, pp. 237-252, 2015.

[19] M. Falkmer, K. Anderson, A. Joosten, and T. Falkmer, "Parents' Perspectives on Inclusive Schools for Children with Autism Spectrum Conditions," Int. J. Disabil. Dev. Educ., vol. 62, no. 1, pp. 1-23, 2015.

[20] A. Sunandar and A. Dian Firdiana, "Management of Special Education: Study of Effectivenes on Inclusion Education Service," in Proceedings of the 3rd International Conference on Education and Training (ICET 2017), 2017.

[21] D. Slavit, T. H. Nelson, and K. Lesseig, "The Teachers' Role in Developing, Opening, and Nurturing an Inclusive STEM-Focused School," Int. J. STEM Educ., vol. 3, no. 1, 2016. 